\title{
CHARACTERIZATION OF SULFATE REDUCING BACTERIA FROM BIOFILM SULFATE REDUCTION AND CU PRECIPITATION BIOREACTOR (BATCH CULTURE).
}

\author{
Tyas Nyonita Punjungsari \\ Balitar Islamic University \\ Email : tyasnyonita@gmail.com
}

\begin{abstract}
The biofilm is a microbial community structure formed on the zeolite surface in a sulfate reduction bioreactor and $\mathrm{Cu}$ deposition using a SRB consortium. The biofilm soluble microbial solvent is expected to have the capability in sulfate reduction and $\mathrm{Cu}$ deposition. Characterization of isolates is required for the optimization of pure culture . The aim of this study is to isolate and characterize the biofilm sulfate reducing bacteria in the sulfate reduction bioreactor and the precipitation of $\mathrm{Cu}$ in Batch Culture by a consortium of Sulfate Reducing Bacteria. The method used in this study cultivation was done by using postgate $B$ medium, isolation was done by diluting biofilm on $\mathrm{NaCl}$ salt, bacteria grown on NB and postgate B media, characterization done by morphology and biochemistry. There were 3 isolates of B1 (Metylobacterium), B3 (Desulfucoccus), and B2 (Desulfobacter). B3 (Desulfococcus) has the best ability to reduce sulfate and $\mathrm{Cu}$ precipitation
\end{abstract}

\section{Keywords : Sulfur Reducing Bacteria (SRB), Biofilm, Sulfate, Cu.}

Received: 26 August, 2017; Accepter: 10 September, 2017

\section{INTRODUCTION}

Heavy metal is a pollutant that has a significant effect on the environment, due to its dangerous toxicity to ecology, evolution, nutrition and the environment. Heavy metals generally involve heavy metal and metaloid groups with atomic densities greater than $4 \mathrm{~g} / \mathrm{cm}$ 3 , or five times larger than water (Hawkes, 1997). In the waste nature of the mining industry (acid mine water) contains a large concentration of sulfate. High sulfate concentrations lead to higher bonding of heavy metals formed especially $\mathrm{Cu}$ (copper). High levels of $\mathrm{Cu}$ and sulfate in water may harm water organisms and environmental equilibrium. Handling of sulfates and heavy metals contamination in nature can be done in chemistry, physics and Biology. Chemical and physical handling make a lot of costs and leaving very high residues like sludge, therefore biological handling is recommended for use because it is more economical and produces no residue.

A biological agent which can be used in sulfate reduction and precipitation of $\mathrm{Cu}$ is a consortium of sulfate reducing bacteria (SRB). Consortium usage can be used to reducing bioremediation costs due to high price of pure isolate production. Once the sulfate reduction laboratory and the precipitation of $\mathrm{Cu}$ metal are done by using bioreactor with batch culture 
type. Synthetic waste with a sulfate state of $100 \mathrm{ppm}$ and $\mathrm{Cu} 25 \mathrm{mg} / \mathrm{L}$ was placed on a glass bottle and then added a consortium of sulfate reducing bacteria , carbon source and added zeolite as sticking medium for biofilm formation.

According to (Watnick and Kolter, 2000) biofilms are structures of microbial communities formed on the surface of solids (interfaces). Microorganisms that live by forming biofilms have higher tolerance for physical, chemical, and biological stresses (Gorbushina and Broughton, 2009). Biofilm cells exhibit certain gene expression that encodes the occurrence of quorum sensing or dormancy, to allow for increased resistance to stress (Dickschat, 2010). Thus, forming biofilms is considered a natural strategy of microorganisms to build and retain their niches in the environment against stress (Shemesh et al., 2010). The formation of biofilms by bacteria is useful in bioremidiation and biotransformation technologies (Yamaga et al, 2010). Bioremidiation technology is more effective with the method of immobilization. Immobilization is defined as a technique for limiting the mobility of microbial cells or their enzymes by stimulating their natural survival and catalytic function (Guzik et al 2014).

After an incubation period of waste for 14 days there was a decrease in sulfate and metal concentrations due to the activities of the SRB consortium. Sulfate reducing bacteria (SRB) are highly efficient in degrading various organic pollutants anaerobically and capable of precipitating heavy metals in liquid waste into metal sulfide form (Coates et al., 1999; Uberoi et al., 1997; White and Gadd, 1998; Spear et al., 1999). The sulfate reduction reaction in heavy metal precipitation process is written as follows (Widdel, 1988; McMohan and Daungulis, 2008).

$$
\begin{aligned}
& 2 \mathrm{CH}_{2} \mathrm{O}+\mathrm{SO}_{4}^{2-} \rightarrow \mathrm{S}^{2-}+2 \mathrm{CO}^{2}+2 \mathrm{H}_{2} \mathrm{O} \\
& \mathrm{S}^{2-}+2 \mathrm{CO}^{2}+2 \mathrm{H}_{2} \mathrm{O} \rightarrow 2 \mathrm{HCO}^{3-}+\mathrm{H}_{2} \mathrm{~S} .
\end{aligned}
$$

$\mathrm{CH}_{2} \mathrm{O}$ is a simple carbon source. Inorganic carbon will neutralize $\mathrm{pH}$ and help the deposition of metal carbonate minerals. The dissolved sulfide $\left(\mathrm{H}_{2} \mathrm{~S}, \mathrm{HS} \cdot\right.$, and $\left.\mathrm{S}^{2-}\right)$ reacts with the metal to form precipitated metal sulfide.

$$
\mathrm{H}_{2} \mathrm{~S}+\mathrm{M}^{2+} \rightarrow \mathrm{MS}+2 \mathrm{H}+
$$

$\mathrm{M}$ is a cation metal which uses divalent metal which will react to form a hard-dissolved metal sulfide. In addition, divalent metal can be precipitated as metal hydroxide with neutral pH (Drury, 1999).

Bacteria capable of using sulfate as its last electron acceptor are known as sulfate reducing bacteria. Sulfate reducing bacteria utilize sulfate (SO42-), thiosulfate (S2O32-) and sulfite (SO32-) as terminal electron acceptor in metabolic respiration, which is then reduced to sulfide. According to Fahrudin (2010) based on the use of sulfate reducing sulfate bacteria are divided into two groups namely assimilatory sulfate reduction and dissimilatory sulfate reduction. The microbial group assimilatory sulfate reduction reduces a small amount of sulfate to synthesize sulfurous cell-copolymers, while dissimilatory sulfate reduction uses sulfate to obtain energy. In addition, to meet the needs of life, sulfate reducing bacteria also require organic nutrients generally short - chain organic acids - such as lactic acid and pyruvate, which are generated by other anaerobic bacteria fermentation activities. Sulfate reducing bacteria are anaerobic heterotrophic organisms. To date there have been known more than 10 genera of sulfate 
reducing bacteria. Sulfate reducing bacteria known and widely found in nature include Desulfovibrio and Desulfotomaculum (Moodie and Ingledew, 1991). Based on the decomposition of organic acids, the sulfate reducing bacteria are grouped into two groups (Kleikemper et al., 2002). The first group oxidizes the donor compound imperfectly, and produces the acetate compound. Desulfotomaculum groups that form spores and Desulvofibrio that do not form spores are bacteria that oxidize organic compounds imperfectly. The second group was able to grow using alcohols, acetates, high molecular weight fatty acids, and benzoates, such as Desulfotomaculum acetoxidans, Desulfobacter, Desulfococcus, Desulfosacrina and Desulfonema (Detmers et al., 2001). Some species and genera of anaerobic bacteria can survive temporarily in the presence of oxygen, but require anaerobic environment (without oxygen) for growth.

The objective of this study was to isolate and characterize sulfate reducing bacteria (SRB) which compose biofilms formed on zeolite surface of sulfate remediation process and $\mathrm{Cu}$ metal on batch culture .

\section{MATERIALS AND METHODS}

Isolation of Bacteria In Biofilms

Biofilm taken aseptically into erlemeyer as much as 0,2 - 0.3 gram and then inserted a reaction tube containing $\mathrm{NaCl}$ (salt precipitation) $9 \mathrm{ml}$ and this becomes a dilution factor of $10^{-}$ ${ }^{1}$. The reaction tube containing the biofilm and then vortex for $3-5$ minutes. After vortex the solution is then diluted in series until the dilution level is $10^{-3}, 10^{-4} \cdot 10^{-5}$. Then from the $10^{-3}$, $10^{-4}, 10^{-5}$ dilution factor was taken $0.1 \mathrm{ml}$ and inoculated on solid medium by pour plate method. The medium used is a solid NB medium (NB added agar). Cultures that grow will form colonies on sub surface media or on the surface of the media. After the pour plate is done inoculation with streak method on the media to minimalist and media for minimalism that has been added molasses to determine the ability of bacterial consortium in using molasses.

\section{Characterization of Bacterial Isolates}

Characterization is performed to determine the character possessed by isolate either morphologically or biochemically. The observed characteristics include gram-positive, respiratory (aerobic, microaerophylic, facultative anaerobes), motile or non-motile motifs, cell shape, colonic form, sugar fermentation, indol formation, capable of producing catalase enzymes, nitrate reduction, hydrogen sulfide production, and hydrolysis of starch. The characters obtained are then matched with Bergey's Manual of Determinative Bacteriology (Holt et al., 1994) .

\section{Gram Testing}

The reaction is determined based upon Gram staining method such as that developed in order by Lay (1994). After Gram staining, preparations were observed with microscope, to see the shape of the cell and Gram reaction. Gram positive bacteria appear purple until blue color while Gram negative is pink.

\section{Cellulase test}

As many as 100 microliter suspens bakteri inoculated in test made in the LA media with $\mathrm{CMC}$ medium in a Petri dish and then incubated in the incubator for 24 hours at $37{ }^{\circ} \mathrm{C}$. The positive test is indicated by producing clear zone around the area of inoculation (Meryandini et al ., 2009). 
Starch hydrolysis test

A total of 100 microliters of suspension of the test bacteria were inoculated on a hole in a starch-containing NA medium, then incubated for $24 \mathrm{~h}$ in an incubator at $37^{\circ} \mathrm{C}$. The positive test is shown by forming a clear zone around the inoculation area (Hastuti et al., 2012).

Aerobic-anaerobic respiration test

The cultures are inoculated on a solid medium that blocks the blue timol in a way split test media in 2 parts on tube reactor, then inoculate culture by piercing the microbe to be tested on 2 different tubes, where one of the tube is filled / covered with paraffin liquid. Then incubated for 3-4 days at room temperature. The color change from blue to yellow to the media indicates that the isolates are positively capable of anaerobic life (Lay 1994).

Testing of Isolate Capability in Reducing Sulfate and precipitating $\mathrm{Cu}$.

Prepares $200 \mathrm{ml}$ of liquid postgate B medium which has added sulfate and $\mathrm{Cu}$ metal into a $500 \mathrm{ml}$ transparent glass bottle. It was then added to isolate bacteria composing biofilms that had been isolated and morphologically and biochemically characterized. The addition of isolates into a transparent glass bottle of $500 \mathrm{ml}$ is done by adding $10 \mathrm{ml}$ of sterile distilled water added to each tube containing microbial isolates (bacteria or fungi) and then poured in $200 \mathrm{ml}$ of liquid medium in batch culture. Microbes are incubated for 7 to 14 days. Observed color change, $\mathrm{pH}$, sulfate concentration and $\mathrm{Cu}$ batch culture concentration at incubation days 0 , day 3 , and day 14 .

\section{RESULTS AND DISCUSSION}

\section{Isolation and Characterization of Biofilm Composition Isolates}

From biofilm batch culture found 8 isolates consisting of 3 isolates of bacteria 5 isolate molds. Isolate was obtained by taking 1 gram of zeolite from batch culture to dissolve at $9 \mathrm{ml}$ $10 \% \mathrm{NaCl}$, in the hope that microorganisms attached to zeolite will be dissolved and dissolve on $10 \% \mathrm{NaCl}$, after dissolved dilution was done at level $10^{-5}, 10^{-6}$, and $10^{-7}$ to be grown on postgate B solid to know the isolates capable of using sulfate. Character of three bacterial isolates can be seen in table 1 .

According to Bergey's Manual Determinative of Bacteriology which is a member of sulfate reducing bacteria is a bacterium with round, oval, stem, vibrioid, and spiral forms, the colony forms filamentous, mostly gram-negative genera, filamentouse, usually gram-positive spores, some motile non motile, colonies on agar are usually yellow brownish, pink, or reddish, but usually there is also a white, anaerobic colony; reducing sulfate to form $\mathrm{H}_{2} \mathrm{~S}$, there are intermediate products of acetate. Based on the characteristics of the three isolates (table 1 ) only isolates B2 and B3 can be expressed as part of the sulfate reducing bacteria group, since they have anaerobic properties, whereas B1 is microaerophylic.

Based on the suitability of characters generated with characters loaded on Bergey's Manual Determinative of Bacteriology B3 belongs to the genus group Desulfococcus, B2 with the genus Desulfobacter, whereas B1 is similar to the genus Metylobacterium. However, in B1 there are several characteristics that correspond to the SRB, namely coccus (round), non motile, filamentous and able to use sulfate, because when grown on postgate B media can be growth.

\section{The ability of isolates to reduce sulfate and precipitate $\mathrm{Cu}$ metal}

After characterization, 2 isolates of the sulfate reducing bacteria were selected . Isolates were included in a $100 \mathrm{ppm}$ sulfate synthetic waste and $\mathrm{Cu} 25 \mathrm{mg} / \mathrm{L}$, then incubated for 14 
days. As a comparison, we observed the activity of mold isolates obtained from biofilm . Each of them observed its ability to precipitate $\mathrm{Cu}$ metal and reduce sulfate in batch culture. Indicators used here, sulfate constituent concentrations, and $\mathrm{Cu}$ precipitation.

Based on figure 1 it is known that in the liquid medium of NB2 (Desulfobacter) and NK4 (Chrysossporium xerophilum) sulfate concentration on day 3 was $329 \mathrm{mg} / \mathrm{L}$ and $314 \mathrm{mg} / \mathrm{L}$, then decreased at day 14 to $321 \mathrm{mg} / \mathrm{L}$ and $287 \mathrm{mg} / \mathrm{L}$, this may occur due to the manufacture of synthetic waste (liquid media) of the material the solid material is then dissolved, so it can be assumed that on the 0th day it is not fully absorbed and the 3rd day is completely dissolved so the concentration increases, and on the 14th day there is a decrease. On the 3rd day of work the isolates of NB2 (Desulfobacter) and NK4 (Chrysossporium xerophilum) in reducing sulfate were not too good as they were still in lag phase. The lag phase in microbes is a condition in which new microbes adapt to their new environment, the availability of different nutrients from the initial state. The duration of the lag phase may vary with each isolate depending on the age of the isolate, or the isolates were previously stored in a cold state.

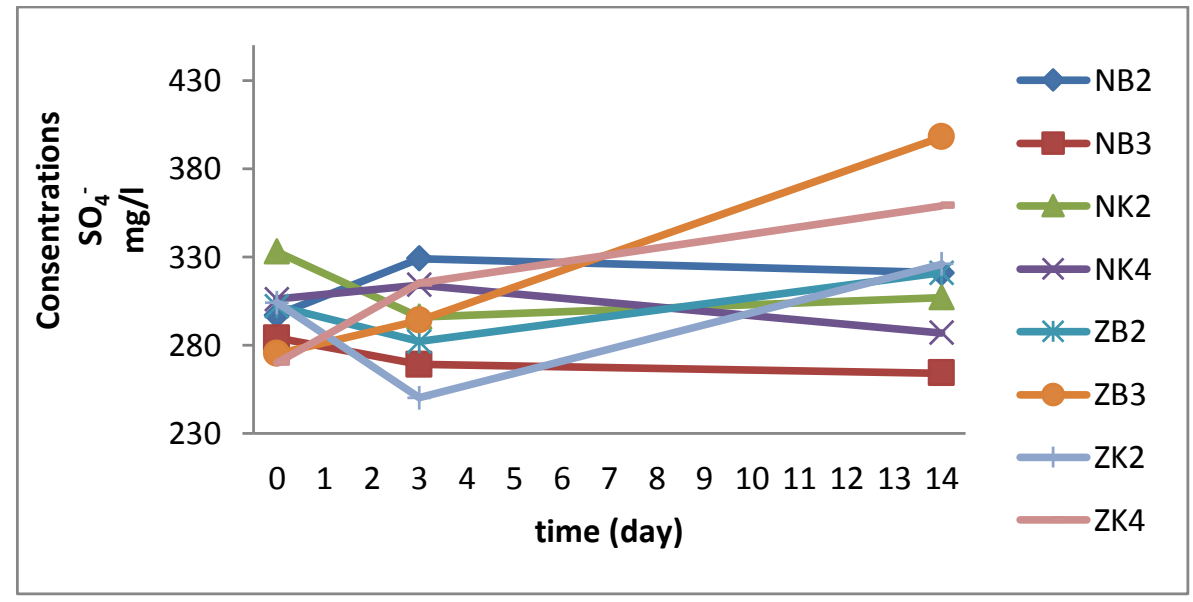

Figure 1. Sulfate fluctuation diagram during 14 days incubation period based on ability isolates NB2, NB3, NK2, NK4, ZB2, ZB3, ZK4

$$
\begin{aligned}
& \text { Information: } \\
& \text { NB2 = Isolate B2 without adding Zeolite } \\
& \text { NB3 = Isolate B3 without Zeolite addition } \\
& \text { NK2 = Isolate K2 without adding Zeolite } \\
& \text { ZB2 = Isolate B2 with addition of Zeolite } \\
& \text { ZB3 = Isolate B3 with addition of Zeolite } \\
& \text { ZK2 = Isolate K2 with addition of Zeolite } \\
& \text { ZK4 = Isolate K4 with Zeolite addition }
\end{aligned}
$$

While for isolates other than isolate NB3 decreased on day 3 and increased on day 14, this situation can occur because in batch culture there is no addition of nutrient to life of isolate. If the growth of the isolate continues to increase while the nutrient does not increase then the isolate will be in the stationary phase. The stationary phase is the response of the isolates to the lack of starvation. If things get worse, it will lead to the phase of death, a condition in which microbes have been unable to sustain their lives due to their minimal nutrients and the greater 
amount of waste products that are toxic to the microbes themselves. Therefore on day 14 it is not a decrease in sulfate concentration. The sequence for the NB3 isolate showed excellent results that were able to decrease the sulfate concentration on the 3rd day by $269 \mathrm{mg} / \mathrm{L}$ and the 14th day to $264 \mathrm{mg} / \mathrm{L}$, so it could be expressed that the isolates (Desulfococcus) were able to use molasses as source carbon in reducing sulfate.

Based on Figure 2 it is known that $\mathrm{p}$ a 3rd day there is a decrease of $\mathrm{Cu}$ content on all liquid media of each isolate either with or without added zeolite. Batch culture using zeolite experience a highest decrease in the concentration of dissolved $\mathrm{Cu}$ with an average reduction of $\mathrm{Cu}$ concentration of $2.982 \mathrm{mg} / \mathrm{L}$, on the other hand from the batch culture without the addition of zeolite that only experienced $\mathrm{Cu}$ degradation concentration of $2.096 \mathrm{mg} / \mathrm{L}$. So it can be said zeolite give effect to the decreasing of $\mathrm{Cu}$ concentration.

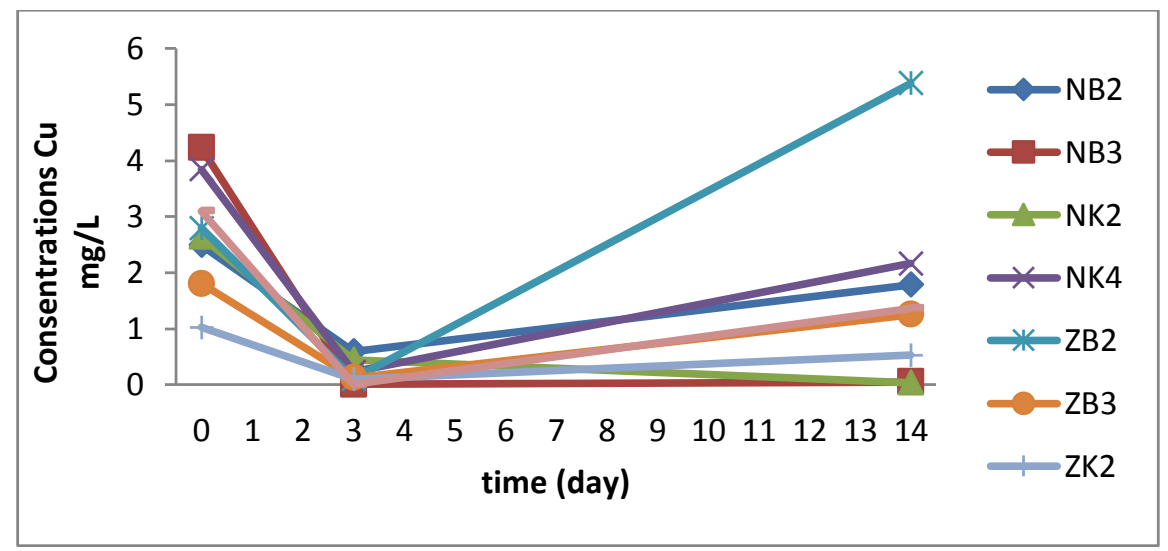

Figure 2. Cu fluctuation diagram during the 14 days incubation period based on ability isolates NB2, NB3, NK2, NK4, ZB2, ZB3, ZK4

Information:

NB2 = Isolate B2 without adding Zeolite

NB3 = Isolate B3 without Zeolite addition

$\mathrm{NK} 2$ = Isolate $\mathrm{K} 2$ without adding Zeolite

$\mathrm{ZB} 2$ = Isolate B2 with addition of Zeolite

$\mathrm{ZB} 3$ = Isolate B3 with addition of Zeolite

$\mathrm{ZK} 2$ = Isolate $\mathrm{K} 2$ with addition of Zeolite

ZK4 = Isolate K4 with Zeolite addition

On the 14th day of the incubation period, the concentration of $\mathrm{Cu}$ increases when compared to day 3 . This can happen because in batch culture there is no nutrient added to the life of isolates. If the growth of isolate continues to increase as the n nutrient does not increase, the isolates will be in the stationary phase. Stationary phase is the response of isolates to the lack of nutrients in the environment (starvation). If the situation gets worse, it will be shortly lead to the death phase, a state where the microbes were not able to survive because of the minimal nutrients available and big increasingly residual substances which are toxic to the microbes themselves. Therefore on the 14th day there has been no decreasing in $\mathrm{Cu}$ concentrations.

In addition to the bacterial growth phase, increased soluble $\mathrm{Cu}$ concentrations may occur as the sulfate concentration increases as shown in FIG . 1 . Increasingly ba a multitude of metal deposited in reducing the ability of microbial sulfate se diminishing, so that the $\mathrm{pH}$ of the 
previously neutral or lead base becoming more acidic leaching as resulted. This process causes the higher dissolved $\mathrm{Cu}$ concentration.

While on result of NK2 (Aspergillus vesicolor) on batch culture method without zeolite addition decreased either on day 3 or day 14 that is equal to $0,4521 \mathrm{mg} / \mathrm{L}$ at $3 \mathrm{rd}$ and 0,0412 $\mathrm{mg} / \mathrm{L}$ on day 14. This result is also supported by its sulfate concentration value and its $\mathrm{pH}$, which, according to Fig. 8, has an increase towards base on day 3 and decreases slightly in 14 days but is still within the nearly equal $\mathrm{pH}$ value range. Aspergillus is one of the most numerous fungus members, in addition to Penicilium and Fusarium. Aspergillus is able to grow at high temperatures and high chemical content (Pitt and Hocking, 2013).

From the above description it can be seen that the isolates having the best ability to reduce sulfate and to assay $\mathrm{Cu}$ are isolates of B3 that are similar to the genus Desulfococ cus and K2 isolates that resemble the genus Aspergillus vesicolor. Isolate B3 (Desulfococcus) was able to

\begin{tabular}{|c|c|c|c|c|}
\hline Character & B1 & B2 & B3 & Bergey's \\
\hline Colony color & White & Brownish yellow & Brownish yellow & $\begin{array}{l}\text { brownish } \\
\text { yellow, pink, } \\
\text { reddish, there is } \\
\text { also a white } \\
\text { color }\end{array}$ \\
\hline Colonies & Circulare & Filamentouse & Filamentouse & Filamentouse \\
\hline Colony surface & Flate & Flate & $\begin{array}{l}\text { Growth into } \\
\text { medium }\end{array}$ & $\begin{array}{l}\text { Growth into } \\
\text { medium }\end{array}$ \\
\hline \multicolumn{5}{|l|}{$\begin{array}{l}\text { The result of } \\
\text { microscope }(400 x)\end{array}$} \\
\hline gram & positive & negative & negative & negative \\
\hline spores & negative & positive & positive & positive \\
\hline Oxygen tolerance & aerob & Anaerobs & Anaerobs & Anaerobs \\
\hline Cell shape & kokus & oval slightly rounded & kokus & $\begin{array}{l}\text { coccus, basil, } \\
\text { oval, vibrioid, } \\
\text { spiral }\end{array}$ \\
\hline Enzyme Catalase & $(+)$ & $(+)$ & $(+)$ & \\
\hline $\begin{array}{l}\text { Mixed acid } \\
\text { fermentation }\end{array}$ & $(+)$ & $(+)$ & $(+)$ & \\
\hline Voges proskeur & $(-)$ & $(-)$ & $(-)$ & \\
\hline Nitrate Reduction & $(+)$ & $(-)$ & $(-)$ & \\
\hline Hydrolysis of starch & $(+)$ & $(+)$ & $(+)$ & \\
\hline Simon citrate & $(+)$ & $(-)$ & $(+)$ & \\
\hline Produce H2S Gas & $(-)$ & $(+)$ & $(+)$ & $(+)$ \\
\hline P. Karbo Glucose & $(+)(-)$ & $(+)(+)$ & $(+)(-)$ & \\
\hline P. Karbo Sukrosa & $(+)(-)$ & $(+)(-)$ & $(+)(-)$ & \\
\hline
\end{tabular}

decrease $\mathrm{Cu}$ and sulfate by $2.089 \mathrm{mg} / \mathrm{L}$ and $10 \mathrm{mg} / \mathrm{L}$ while $\mathrm{K} 2$ isolate (Aspergillus vesicolor) 


\begin{tabular}{lllll} 
P. Karbo Lactose & $(+)(-)$ & $(+)(+)$ & $(+)(+)$ & \\
$\begin{array}{l}\text { P. Karbo Manitol } \\
\text { Motility }\end{array}$ & $(+)(-)$ & $(+)(-)$ & $(+)(-)$ & non motile \\
$\begin{array}{l}\text { Reduce Methylen } \\
\text { Blue }\end{array}$ & $(+)$ & motile & $(-)$ & $\begin{array}{l}\text { motile and } \\
\text { nonmotil }\end{array}$ \\
$\begin{array}{l}\text { Result of } \\
\text { Identification }\end{array}$ & Metylobacterium & Desulfobacter & Desulfococcus & \\
\hline
\end{tabular}

was able to decrease dissolved $\mathrm{Cu}$ and sulfate concentration of $1,301 \mathrm{mg} / \mathrm{L}$ and $13 \mathrm{mg} / \mathrm{L}$. Desulfococcus is one member of the sulfate reducing bacteria capable of oxidizing acetate by using sulfate as an electron acceptor under anoxic conditions (Das et al., 2006).

It is also known that the isolate of biofilm is able to decrease sulfate and precipitate $\mathrm{Cu}$ metal. It is also known that the addition of zeolite gives a good influence to the ability of isolate in reducing precipitate $\mathrm{Cu}$, this is proven by $\mathrm{Cu}$ measurement. Batch culture isolate microbes added zeolite e average decreased dissolved $\mathrm{Cu}$ concentration of $2.982 \mathrm{mg} / \mathrm{L}$, sedimentation without zeolite addition of only $2.096 \mathrm{mg} / \mathrm{L}$. This is because the zeolite can function as a microbial bonding medium in a form biofilm. Immobilization methods by forming biofilms can benefit bacteria in adapting and surviving in environments containing heavy metals.

As for the decrease in sulfate concentration with or without zeolite addition is not very influential to the ability of isolate. Because when viewed from the charts it is known either that it adds zeolite or does not experience fluctuation of sulfate which is not so good, which decreases on the third day and up on day 14. This happens because in the process of forming sulfide that can precipitate the metal from the sulfate in the environment, SRB also produces a sulfate-containing intermediate product, adenosine phosposulfate (APS), therefore a sulfate concentration increase at day 14 .

Table 1 . Character isolates of biofilm bacteria

Description: (+) Shows a positive reaction

(-) Indicates a negative reaction

$(-)(+)$ Negative reaction, formed gas

(+) (-) Positive reaction, not formed gas

$(+)(+)$ Positive reaction, formed gas

\section{CONCLUSIONS}

From the results of research that has been done can be concluded as follows:

Obtained 8 (eight) microbial isolates, 3 isolates of bacteria, 5 isolates of mold. Isolate B3 belongs to the genus group Desulfococcus, B2 with the genus Desulfobacter, whereas B1 has a similarity with the genus Metylobacterium. K1 is a group of Rhizomucor / Mucor, K2 is Aspergillus vesicolor, $\mathrm{K} 3$ is a group of Chrysosporium farinicola, K4 is Chrysossporium xerophilum, K5 is Aspergillus.

Isolates that have the best ability to reduce sulfate and precipitate $\mathrm{Cu}$ are isolates of $\mathrm{B} 3$ that resemble the genus Desulfococcus and K2 isolates that resemble the genus Aspergillus vesicolor. Isolate B3 (Desulfococcus) was able to decrease dissolved $\mathrm{Cu}$ and sulfate concentration by $2.089 \mathrm{mg} / \mathrm{L}$ and $10 \mathrm{mg} / \mathrm{L}$ while isolate $\mathrm{K} 2$ (Aspergillus vesicolor) was able to decrease dissolved $\mathrm{Cu}$ and sulfate concentration by $1,301 \mathrm{mg} / \mathrm{L}$ and $13 \mathrm{mg} / \mathrm{L}$. 


\section{References}

Coates, J. A. 1996. Anaerobic hydrocarbon degradation in petroleum-contaminated harbor sediments under sulfatereducing and artificially imposed iron-reducing conditions. Environ Sci Technol, 30 (9): 2784-2789.

Dickschat, J. 2010. Quorum sensing and bacterial biofilms. Nat. Prod, Rep. 27, 343-369.

Drury, W. 1999. Treatment of acid mine drainage with anaerobic solid substrate reactors. Water Environ. Res, $71: 1244-1250$.

Gorbushina, A., \& Broughton, W. 2009. Microbiology of the a how biological interactions and physical stresses modulate a sophisticated microbial ecosystem. Annu. Rev. Microbiol, 63, $431-450$.

Guzik U, H.-K. K. 2014. Enhancement of bio-degradation potential of catechol 1, 2dioxygenase through its immobilization in calcium alginate gel. Electron $\mathbf{J}$ Biotechnol , $17: 83-88$.

Hawkes, J. 1997. Heavy metals. J Chem Edu: 74:1369-1374.

Holt, J. G., R.Krieg, N., Sneath, P. H., Staley, J. T., \& Wiliams, S. T. 1994. Bergey's Manual of Determinative Bacteriology. Maryland USA: Sanstacne.

Kleikemper, H., S. M., V., S. W., Schmucki, M., Bernasconi, S. M., \& Zeyer, J. 2002. Activity and Diversity of Sulfate-Reducing Bacteria in a Petroleum Hydrocarbon-Contaminated Aquifer. Appl Environ Microbiol. doi: 10.1128/AEM.68.4.1516-1523, 68(4): 1516-1523.

McMahon, M. 2007. Development of a Sulfate Reducing Packed Bed Bioreactor For Use in a Sustainable Hydrogen Production Process. Ontario, Canada. 163p: Thesis.QUEEN'S UNIVERSITY Kingston.

Moodie, A., \& Ingledew, W. 1991. Microbial Anaerobic Respiration. Tempest, Advances in Microbial Physiology. Vol 31. USA: Academic Press Limited.

Shemesh, M., R Kolter, R., \& Losick, R. 2010. The biocide chlorine dioxide stimulates biofilm formation in Bacillus subtilis by activation of the histidine kinase KinC. J. Bacteriol, 192, 6352-6356.

Uberoi, V. a. 1997. Effects of chlorophenols and nitrophenols on the kinetics of propionate degradation in sulfate-reducing anaerobic systems. Environmental Science \& Technology, 31 (6): 1607-1614.

Watnick, P., Kolter, R., 2000. Biofilms, city of microbes. J. Bacteriol. 13, 20-26.

White, C. a. (2000). Copper accumulation by sulfate-reducing bacterial biofilms. FEMS Microbiology Letters, 183: 313-318.

Widdel, F. (1988). Microbiology and ecology of sulfate- and sulfur-reducing. A.J.B. (Ed.), 489495.

Yamaga, F., Washio, K., \& Morikawa, M. 2010. Sustainable biodegradation of phenol by Acinetobacter calcoaceticus P23 isolated from the rhizosphere of duckweed Lemna aoukikusa. Environ. Sci. Technol, 44, 6470-6474. 